\title{
Regulation by FSH and dibutyryl cyclic AMP of the formation of androgen-binding protein in Sertoli cell-enriched cultures
}

\author{
Irving B. Fritz, Focko G. Rommerts, ${ }^{*}$ B. Gregory Louis \\ and Jennifer H. Dorrington \\ Banting and Best Department of Medical Research, University of Toronto, \\ Toronto, Ontario M5G 1L6, Canada
}

\begin{abstract}
Summary. Sertoli cell-enriched preparations from testes of 20-day-old rats were cultured in a defined medium in the presence and absence of FSH or dibutyryl cyclic AMP (dcAMP). Androgen-binding activity was assayed in the culture medium, and related to testicular androgen-binding protein (ABP). The production and secretion of ABP by the Sertoli cell-enriched preparation was increased after FSH or dcAMP treatment of the primary culture. It is concluded that ABP is produced by Sertoli cells. The possibility of involvement of other cell types in the testis in ABP production is discussed.
\end{abstract}

\section{Introduction}

The initial report that testicular androgen-binding activities are decreased after hypophysectomy (Vernon et al., 1972) has been amply confirmed and extended (Hansson et al., 1974; French et al., 1974; Sanborn et al., 1974; Fritz et al., 1974). Administration of FSH to adult hypophysectomized rats increases testicular levels of androgen-binding protein (ABP) (Vernon et al., 1973, 1974). Similar observations have been reported for ABP levels in testes from immature hypophysectomized (Hansson et al., 1973) and adult (Sanborn et al., 1974, 1975) rats.

Sertoli cells have been implicated as the tubular cells responding to FSH administration in vivo (Murphy, 1965; Means, 1974) and it has been shown that FSH elicits increased cyclic AMP production by isolated Sertoli cell-enriched preparations, but not by isolated Leydig or germinal cell preparations (Dorrington \& Fritz, 1974; Dorrington et al., 1974, 1975). It appears likely that ABP may be produced by Sertoli cells because (1) ABP levels in cryptorchid testes, which are deficient in advanced germinal cells, are within or above normal limits when expressed as androgenbinding capacity/mg protein (Vernon et al., 1973, 1974; Sanborn et al., 1974); (2) little or no ABP can be detected in Leydig cells (Vernon et al., 1974; Hansson et al., 1974); (3) ABP levels in testes from sex-reversed adult female mice (SXR mutants) are within normal limits (Fritz et al., 1974), even though no germinal cells are present in these animals (Cattanach et al., 1971); and (4) preliminary observations on Sertoli cell-enriched cultures indicated ABP production which could be stimulated by addition of FSH (Fritz et al., 1974). Additional evidence has been recently provided in reports by Tindall et al. (1974) on ABP levels in tests of 'Sertoli cell only' rats, and by French et al. (1974) and Hansson et al. (1974) on ABP levels in testes made deficient in germinal cells by irradiation.

To test more directly the inference that ABP is produced by Sertoli cells under the regulation of FSH, it would be of advantage to investigate ABP formation by isolated Sertoli cells. We have recently described the properties of Sertoli cell primary cultures, prepared initially from testes of immature rats (Dorrington et al., 1975). We now present results indicating that the addition of either FSH or cyclic AMP derivatives increases the elaboration of ABP by these Sertoli cell-enriched cultures. Some of these data have been presented elsewhere (Fritz et al., 1975).

\footnotetext{
* Present address: Erasmus University, Department of Biochemistry, Division of Chemical Endocrinology, Rotterdam, The Netherlands.
} 


\section{Materials and Methods}

\section{Materials}

Ovine FSH (NIH-S10) was provided by the Endocrinology Study Section, NIH, and a more purified $(\times 50)$ preparation (G4-150c) was a generous gift from Dr H. Papkoff. The $3^{\prime}, 5^{\prime}$-cyclic AMP (cAMP), $\mathrm{N}^{6}, \mathrm{O}^{2}$-dibutyryl cAMP (dcAMP) and $\mathrm{N}^{6}$-monobutyryl cAMP (mcAMP) were purchased from Sigma Chemical Co., St. Louis, Missouri and $\left[{ }^{3} \mathrm{H}\right]$ dihydrotestosterone (DHT) was obtained from NEN Canada Ltd, Montreal. Other sources of materials employed during cell preparation and culture have been described elsewhere (Dorrington et al., 1975).

\section{Cell preparation and culture techniques}

Testes from ten to fifteen 20-day-old Wistar rats were used as starting material for the Sertoli cell preparations. The testes, freed of the tunica albuginea, were chopped into $0.5 \mathrm{~mm}$ segments and then treated with trypsin plus DNase, followed by collagenase digestion as described previously (Dorrington et al., 1975). After exposure to collagenase, the preparation was centrifuged for $2 \mathrm{~min}$ at $400 \mathrm{rev} / \mathrm{min}$ in an International bench model clinical centrifuge, and the pellet was resuspended in $10 \mathrm{ml}$ Hanks Balanced Salt Solution (BSS) supplemented with $1 \%$ bovine serum albumin (BSA). The centrifugation and resuspension were repeated once, and the suspension was transferred to a $50 \mathrm{ml}$ round-bottomed polycarbonate centrifuge tube and allowed to stand for $5 \mathrm{~min}$, after which the supernatant was removed from the settled cell aggregates. The latter were transferred with BSS-BSA (final suspension volume $10 \mathrm{ml}$ ) to a $25 \mathrm{ml}$ graduated cylinder, into which a Dounce ball-head pestle weighing approximately $80 \mathrm{~g}$ was inserted. The clearance in this device was such that the pestle, allowed to fall freely through glycerol in the cylinder, descended at the rate of $1.4 \mathrm{~mm} / \mathrm{sec}$. At the starting position, the head of the pestle was just covered with the cell suspension. The pestle was dropped and slowly raised fifteen times, care being taken to introduce no air bubbles into the suspension. The cell aggregates were washed twice by centrifugation as described above, with BSS containing no BSA, and were then collected by centrifugation. The pellet was resuspended in 10 vols Eagle's minimal essential medium (MEM) (Gibco), supplemented with antibiotics and non-essential amino acids, as in Medium A of Steinberger \& Steinberger (1966), with the exceptions that the final glutamine concentration was $4 \mathrm{~mm}$, and no sodium pyruvate was present. Aliquots $(0.2 \mathrm{ml})$ of the dispersed cell aggregates, which had a diameter of $100 \pm 50 \mu \mathrm{m}$, were plated onto $30 \mathrm{ml}$ Falconware culture flasks such that approximately $10^{5}$ aggregates were present per flask. Supplemented MEM (5 ml) was added, and the flasks were incubated at $32^{\circ} \mathrm{C}$ in a water-saturated atmosphere of $95 \%$ air and $5 \% \mathrm{CO}_{2}$. The culture medium was removed after $24 \mathrm{hr}$, together with all cells not adhering to the flask, and replaced by fresh culture medium containing the components indicated in the Tables and Text-figures. Formation of ABP by cells incubated in the initially protein-free medium was measured in aliquots taken from each vessel at suitable intervals for the duration of the experiment (3-14 days). At the end of this period the cells were removed from the vessels, either mechanically or by exposure to $5 \mathrm{mM}$ EDTA- $0.9 \% \mathrm{NaCl}, \mathrm{pH} 6$, and disrupted by sonication. Total cell protein was determined either by the method of Lowry et al. (1951) or by that of Heil \& Zillig (1970). DNA was determined fluorimetrically as described by Kissane \& Robins (1958). In a typical preparation, $2.2 \mathrm{~g}$ of chopped tubules were obtained from the testes of fourteen rats, and these yielded $0.55 \mathrm{~g}$ of packed cells at the collection step. Each flask received approximately $1 \mathrm{mg}$ of cell protein.

After being cultured for various periods of time, cells from some of the flasks were removed by trypsinization as described by Dorrington et al. (1975), fixed in glutaraldehyde and carried through conventional procedures for the preparation of electron micrographs (Plate 1). Differential cell counts were determined by counting $500-1000$ cells in different sections identified structurally by electron microscopic examination.

\section{Analysis of $A B P$}

Levels of ABP were analysed by equilibrium dialysis. Dialysis cells were made by knotting 2-in. lengths of moistened $0 \cdot 22$-in. dialysis tubing at one end and forcing the other end over a short length 
of glass tubing obtained by cutting a Pasteur pipette at the upper constriction. A rubber ring was placed over the assembly, to ensure a seal and to provide support for the cell during dialysis. Holes of the correct diameter were made in a plastic Petri dish cover with a hot Pasteur pipette. The cover was placed over a vessel containing $1 \mathrm{nM}-\mathrm{DHT}$ (sp. act. $44 \mathrm{Ci} / \mathrm{mmol}$ ) in a solution containing $100 \mathrm{~mm}-\mathrm{KCl}$, 2 mM-EDTA, 10 mM-tris- $\mathrm{HCl}$ buffer at $\mathrm{pH} 7 \cdot 4$ and $0.02 \%(\mathrm{w} / \mathrm{v}) \mathrm{NaN}_{3}$. Dialysis cells were inflated with a syringe by applying suitable pressure for a few seconds. The open cells were filled with $250 \mu \mathrm{I}$ aliquots of the solutions to be assayed and inserted through the holes in the support so that the level of liquid in the cells was at or below that of the exterior fluid. The volume of exterior fluid was at least thirtyfold greater than the total volume within all cells, thus ensuring the removal of endogenous steroids during dialysis. The dialysis was carried out at $4^{\circ} \mathrm{C}$ for periods of 15 to $48 \mathrm{hr}$, the external fluid being stirred magnetically throughout this period. Two $100 \mu \mathrm{l}$ aliquots were then removed from each cell, and counted in Aquasol in a Searle Instrumentation Isocap liquid scintillation spectrometer. Data obtained were corrected for quenching and used to calculate the pmol of steroid bound by medium in the flask, which was converted at the end of the experiment to amounts bound $/ \mu \mathrm{g}$ cell DNA in the flask, or per unit of androgen binding activity during the initial period, as indicated in 'Results'. Dialysis efficiency was monitored by including with each group of assays a cell containing fresh culture medium alone. In experiments designed to test the reliability of the assay, androgenbinding activity in culture medium from which incubating cells had been removed was found to remain constant for up to 10 days under conditions of cell culture, and for at least $48 \mathrm{hr}$ under conditions of the equilibrium dialysis. Binding of $\left[{ }^{3} \mathrm{H}\right] \mathrm{DHT}$ was linearly dependent on the amount of medium protein added to the dialysis cells. Spurious binding of DHT to albumin-like proteins with low affinity for androgens was negligible because the protein concentration in the cell was less than $10 \mu \mathrm{g} / \mathrm{ml}$ at all times.

Dialysis cells could be re-used if they were washed thoroughly, soaked for at least $24 \mathrm{hr}$ in $3 \%$ formaldehyde and then rinsed in distilled water for $30 \mathrm{~min}$ before use.

In separate experiments, the amounts of $\left[{ }^{3} \mathrm{H}\right] \mathrm{DHT}$ bound to ABP were evaluated by 'steadystate' polyacrylamide gel electrophoresis, essentially as described by Ritzén et al. (1974). For these experiments, culture media from several Petri dishes were pooled and concentrated over tenfold at $4^{\circ} \mathrm{C}$ by ultrafiltration in an Amicon stirred-cell apparatus. In order to avoid loss of material during concentration, it was necessary to pre-saturate the membranes with protein by concentrating a $0.1 \%$ solution of BSA to $1 \%$ and then washing the membrane with $0.9 \% \mathrm{NaCl}$ until no more u.v.absorbing material was released. No steroid-binding activity appeared in culture medium lacking ABP when volume reduction was carried out over these albumin-saturated membranes.

\section{Results}

An electron micrograph of the cell preparation employed in these studies is shown in Plate 1. The percentage of Sertoli-like cells in the preparation varied from $60 \%$ before culture to over $90 \%$ after 3 days in culture. Among the contaminating cells, spermatogonia were the primary cell type observed.

Intracellular $\mathrm{ABP}$ activity in the cells initially plated in culture flasks was less than $0.002 \mathrm{pmol} / \mu \mathrm{g}$ DNA, and did not appreciably change during culture. In contrast, ABP activity released into the medium by FSH-treated cells was nearly $0.1 \mathrm{pmol} / \mu \mathrm{g}$ DNA during 14 days in culture (Text-fig. 1a).

The appearance of ABP in the culture medium during various periods of incubation of a Sertoli cell-enriched preparation is depicted in Text-fig. 1. Addition of FSH increased the cumulative appearance of ABP in the medium. The most striking FSH effects were evident after prolonged culture, since ABP production by untreated cells tended to decrease by the 8 th day of culture. There was an increase of less than twofold after culture for $72 \mathrm{hr}$ of FSH-treated cells, but the stimulation of ABP appearance in the medium was greater than $\times 2.5$ in cells treated with FSH for 14 days (Text-fig. 1a).

Similar FSH effects were evident when the data were expressed as shown in Text-fig. 1(b). This form of expression has been routinely employed, since results could be normalized without terminat- 
ing the experiment or consuming cellular material. The ABP levels/unit medium protein are not reported because the low amounts of protein in the medium, always $<10 \mu \mathrm{g} / \mathrm{ml}$, varied as a consequence of loss of protein from dying cells.

The results shown in Text-fig. 1(c) demonstrate that the addition of $0.1 \mathrm{mM}$-dcAMP increased ABP appearance even more than did the addition of FSH. After incubation for $72 \mathrm{hr}$ there was about $\times 2 \mathrm{ABP}$ in the medium bathing FSH-treated cells, and about $\times 3 \mathrm{ABP}$ in that from dcAMP-treated cells. After 10 days of culture, the increases were approximately $\times 3$ and $\times 4.5$, respectively, in FSH-

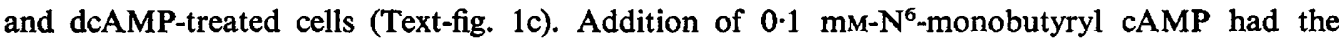
same effect on ABP production as had dcAMP, whereas treatment with 1 mM-cAMP resulted in a stimulation of ABP production comparable to that obtained in FSH-treated preparations. Addition of sodium butyrate $(0.1 \mathrm{mM}), 5^{\prime}$ AMP $(1.0 \mathrm{mM})$ or $\mathrm{O}^{2}$-monobutyryl cAMP $(0.1 \mathrm{mM})$ was without effect. Purified FSH at a concentration of $0.2 \mu \mathrm{g} / \mathrm{ml}$ was as effective as NIH-FSH at $5 \mu \mathrm{g} / \mathrm{ml}$ (Fritz et al., 1975).
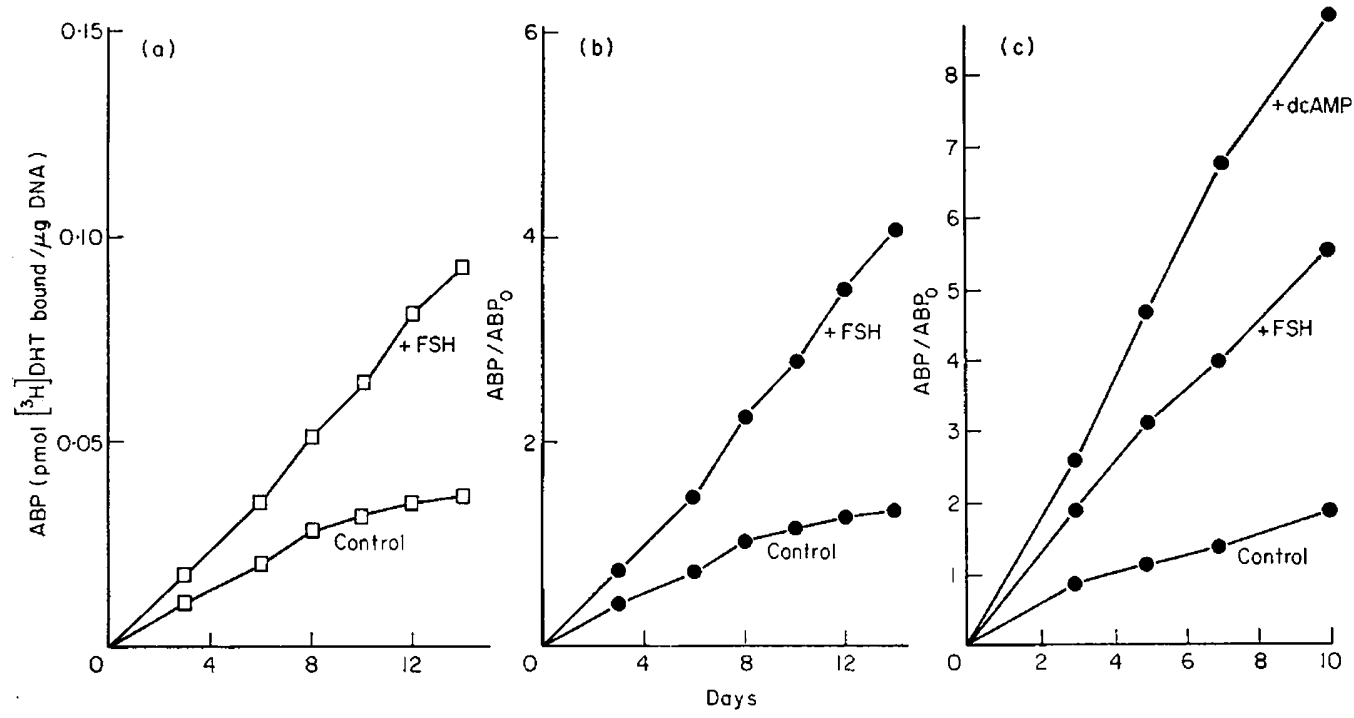

Text-fig. 1. The time course of appearance of androgen-binding activity into the medium of Sertoli cellenriched cultures in the presence or absence of FSH or dcAMP. Cells were isolated and placed in culture, stabilized for $24 \mathrm{hr}$ and subsequently treated with $5 \mu \mathrm{g}$ ovine FSH (NIH-S10)/ml as described in the text. At each point shown, the culture medium was removed from each flask for ABP assay, and fresh medium was added. The graphs are cumulative from the initial time of treatment (Day 0). Medium from each of four flasks was assayed separately, and the average androgen-binding activity for the four determinations is represented by each point. In all cases, androgen-binding activity was assayed by equilibrium dialysis against $1 \mathrm{~nm}-\left[{ }^{3} \mathrm{H}\right] \mathrm{DHT}$, as described in the text. (a) The data are expressed as pmol $\left[{ }^{3} \mathrm{H}\right] \mathrm{DHT}$ bound $/ \mu \mathrm{g}$ DNA in the cells at the end of culture; (b) the same data are expressed as pmol $\left[{ }^{3} \mathrm{H}\right] \mathrm{DHT}$ bound at a designated time/pmol [ ${ }^{3} \mathrm{H}$ ]DHT bound during the initial $24 \mathrm{hr}$ of culture; (c) data expressed as in (b).

A summary of data from experiments on seven different Sertoli cell-enriched preparations, each incubated for $72 \mathrm{hr}$ under identical conditions, is given in Table 1. The levels of ABP in the medium in control flasks varied among experiments for unknown reasons. In all cases, however, addition of FSH or dcAMP increased the appearance of ABP.

The properties of ABP in the culture medium were investigated. The DHT binding was abolished by treatment with $100 \mu \mathrm{g}$ protease (type IV, Sigma, from Streptomyces)/ml for $60 \mathrm{~min}$ at $32^{\circ} \mathrm{C}$. The apparent $\mathrm{K}_{d}$ for DHT binding was estimated to be 2-3 nM by Scatchard plots of results obtained with the dextran-charcoal method described previously (Vernon et al., 1974). When analysed by steady-state polyacrylamide gel electrophoresis (Ritzén et al., 1974), the DHT-binding protein in the culture medium had a relative mobility identical to that obtained for ABP extracted from 


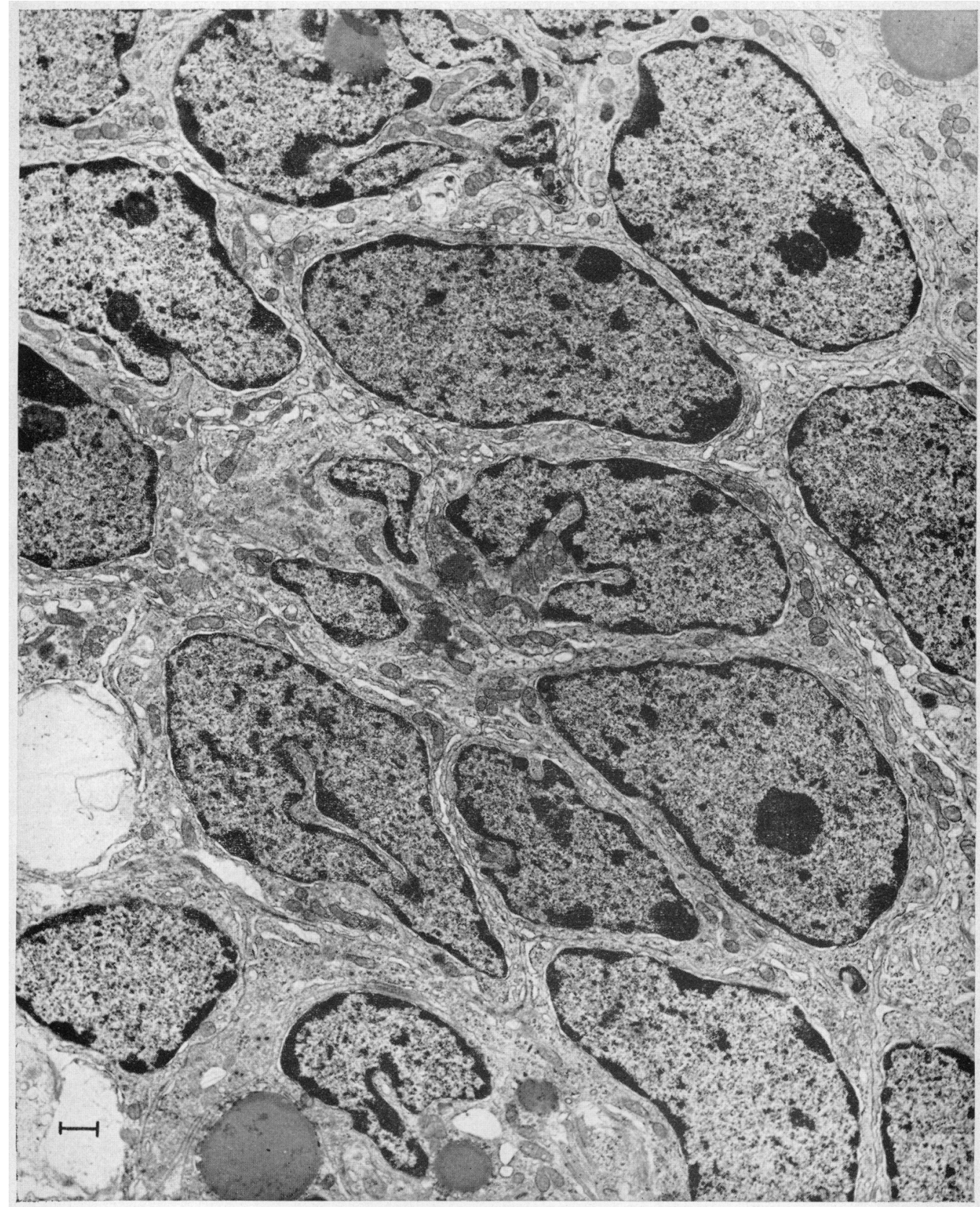

Electron micrograph of cultured Sertoli cell-enriched preparation. Cells were removed after 72 hr in culture by trypsinization, followed by treatment with soybean antitrypsin as described by Dorrington $e t a l$. (1975). The washed pellet was fixed in $3 \%$ glutaraldehyde in $0.1 \mathrm{~m}$ Millonig phosphate bufter for 30 min at $32 \mathrm{C}$, followed by post-fixation in $2 \%$ osmium tetroxide in $0.1 \mathrm{~m}$ Millonig buffer at $\mathrm{pH} 7.4$ for $60 \mathrm{~min}$. The preparation was dehydrated, embedded in Epon, sectioned and stained by conventional electron microscopic procedures. The photomicrograph was taken with an RCA EM, with an original magnitication of $\times 2800$. Bar $=1 \mu \mathrm{m}$. 
Table 1. The influence of FSH and dcAMP on androgen-binding activity in the medium from Sertoli cell-enriched cultures

\begin{tabular}{|c|c|c|c|c|c|c|}
\hline \multirow[b]{2}{*}{ Exp. } & \multirow{2}{*}{$\begin{array}{c}\text { ABP }(-24 \text { to } 0 \mathrm{hr}) \\
\text { (pmol DHT } \\
\text { bound/flask) }\end{array}$} & \multicolumn{3}{|c|}{$\mathrm{ABP}(0$ to $72 \mathrm{hr}) / \mathrm{ABP}(-24$ to $0 \mathrm{hr})$} & \multicolumn{2}{|c|}{$\%$ Stimulation } \\
\hline & & Control & $+\mathrm{FSH}$ & +dcAMP & $+\mathrm{FSH}$ & +dcAMP \\
\hline 1 & $2.05(8)$ & $0.90(3)$ & $1.93(3)$ & $2 \cdot 53(2)$ & 114 & 181 \\
\hline 2 & $2 \cdot 79(6)$ & $0.81(2)$ & $1 \cdot 20(2)$ & $1.44(2)$ & 48 & 79 \\
\hline 3 & $2 \cdot 17(8)$ & $0.78(4)$ & & $2.04(4)$ & & 162 \\
\hline 4 & $1.43(4)$ & $0.68(2)$ & & $1.79(2)$ & & 163 \\
\hline 5 & $3.87(12)$ & $0.56(4)$ & $0.76(4)$ & $1.02(4)$ & 36 & 82 \\
\hline 6 & $2 \cdot 18(10)$ & $0.61(3)$ & 0.85 (4) & $1 \cdot 13(3)$ & 39 & 85 \\
\hline \multirow[t]{4}{*}{7} & $1 \cdot 62(5)$ & $0.43(2)$ & $0.75(3)$ & & 74 & \\
\hline & & & & Mean & $60 \cdot 6$ & $122 \cdot 4$ \\
\hline & & & & S.E.M. & $9 \cdot 9$ & $14 \cdot 2$ \\
\hline & & & & $P_{0}$ & $<0.001$ & $<0.001$ \\
\hline
\end{tabular}

Fresh medium containing $5 \mu \mathrm{g}$ ovine NIH-FSH/ml or $0.1 \mathrm{mM}$-dcAMP was added to cell culture flasks after the initial culture period of $24 \mathrm{hr}$ (see 'Materials and Methods'). Control flasks received medium containing no hormone. Samples were obtained after incubation for a further $72 \mathrm{hr}$. Androgen-binding activity was assayed by equilibrium dialysis against $1 \mathrm{nM}$ labelled DHT, as described in the text. The numbers of flasks treated are shown in parentheses. $P_{0}$ refers to the null hypothesis that the mean stimulation reported is not significant and was determined by the Aspen-Welch $t$ test.

testis (Text-fig. 2). The ABP in the culture medium of control, FSH-treated and dcAMP-treated cells had identical electrophoretic mobilities in this system.

\section{Discussion}

The androgen-binding activity appearing in the medium during culture of the Sertoli cell-enriched preparations most probably represents net ABP production and release. This conclusion is justified on the basis that the DHT-binding activity in the medium was far greater than that which could be detected in the cells at the time of initiation of culture. Since little intracellular ABP could be detected after culture for various times, we infer that ABP produced by the cells is rapidly released into the medium. The possibility remains to be examined that $\mathrm{ABP}$ is produced from a precursor, and that the $\mathrm{ABP}$ activity measured does not necessarily arise de novo from new protein synthesis. In experiments reported elsewhere, the incorporation of $\left[{ }^{3} \mathrm{H}\right]$ leucine into total TCA-precipitable proteins by the Sertoli cell-enriched preparation has been observed to be increased in cells previously treated with FSH or dcAMP (Dorrington et al., 1975). This incorporation was found to be consistent with de novo protein synthesis, since it was abolished by cycloheximide. The effects of FSH and dcAMP on the incorporation of labelled amino acids into ABP by the Sertoli cell-enriched preparation are under investigation.

The cells in the preparation primarily responsible for elaborating ABP into the culture medium were probably Sertoli cells. This tentative conclusion is based on the findings that the preparations continued to respond to FSH or dcAMP with increased production of ABP during 10 days in culture, a time at which most germinal cells have degenerated and been removed from the culture flask during the changes of medium. Most of the cells remaining attached to flasks have structural properties (Tung et al., 1974, 1975) which are characteristic of Sertoli cells in vivo, as described by Flickinger (1967), Dym (1973), and Fawcett (1975). The mitotic index in Sertoli cell preparations was observed to be less than $0.03 \%$ under conditions of culture employed (Tung et al., 1975). Our data do not rule out the possibility that other contaminating cell types could have contributed to ABP production. It appears unlikely, however, that spermatogonia are required for ABP production by Sertoli cells, because ABP levels/mg protein in testes from adult SXR mice which lack all germinal cells (Fritz et al., 1974), and the testicular ABP levels in irradiated rats deficient in spermatogonia (Tindall et al., 1974), are normal. 


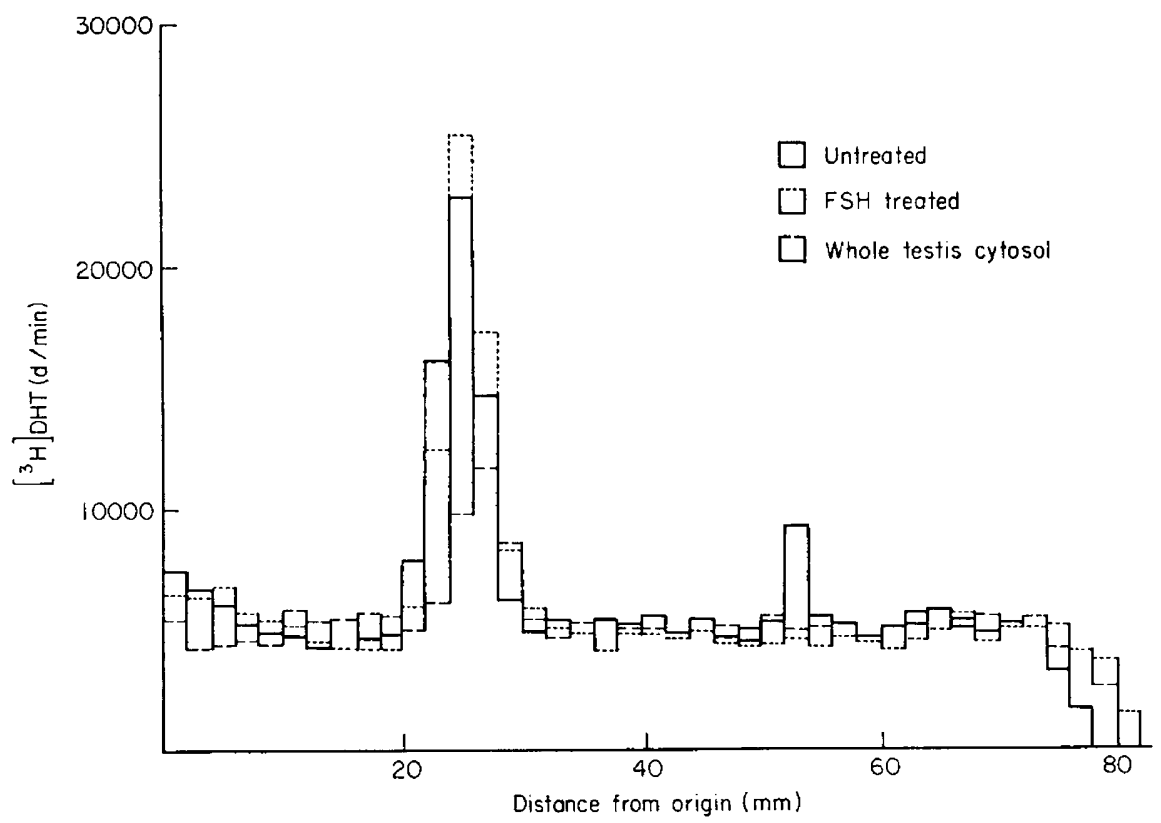

Text-fig. 2. Steady-state polyacrylamide gel electrophoresis of concentrated culture medium from untreated and FSH-treated Sertoli cells and of whole-testis cytosol. The pooled culture medium was concentrated as described in the text. A whole-testis cytosol fraction was obtained from the testes of a $230 \mathrm{~g}$ male Wistar rat as described by Vernon et al. (1974), and concentrated in the same way. Samples to be analysed were first dialysed for $20 \mathrm{hr}$ against the $\left[{ }^{3} \mathrm{H}\right] \mathrm{DHT}$-containing buffer used in the ABP assay. Aliquots $(200 \mu \mathrm{l})$ were run on $5 \times 80 \mathrm{~mm}, 7 \%$ cylindrical polyacrylamide gels as described by Davis (1964), except that the acrylamide solution used to make the gels contained $10 \%$ glycerol and $1 \mathrm{nM}-\left[{ }^{3} \mathrm{H}\right] \mathrm{DHT}$ (Ritzén et al., 1974). Gel slices ( $2 \mathrm{~mm}$ ) were incubated at room temperature with $0.1 \mathrm{ml} 30 \% \mathrm{H}_{2} \mathrm{O}_{2}$ for $18 \mathrm{hr}$, after which Aquasol (10 ml/slice) was added and radioactivity was determined. The three gels shown contain protein from the equivalent of: $7 \mathrm{ml}$ culture medium from untreated cells ( $86 \mu \mathrm{g}$ protein); $5 \cdot 25 \mathrm{ml}$ culture medium from FSH-treated cells ( $66 \mu \mathrm{g}$ protein); $0.64 \mathrm{mI}$ of $100,000 \mathrm{~g}$ supernatant fraction from adult, normal rat testis homogenate $(970 \mu \mathrm{g}$ protein). Total DHT-binding activities were 1·103, 1.203 and $0.245 \mathrm{pmol}$ respectively in these protein fractions. By equilibrium dialysis measurements, the androgen binding activity $/ \mathrm{ml}$ medium was increased by $45.4 \%$ in FSH-treated cells. By analysing the counts of $\left[{ }^{3} \mathrm{H}\right]$ DHT bound to protein in the peaks shown, the corrected increase in ABP from the FSH-treated sample was $52 \cdot 2 \%$. Comparable results were obtained in three separate polyacrylamide gel electrophoretic experiments.

In order to determine the distribution of DHT-binding proteins on polyacrylamide gels, it was necessary to concentrate the pooled medium from several vessels containing the same components. As shown in Text-fig. 2, only one discrete region was labelled, and the amount of binding in this region was increased by prior treatment of the cells with FSH or dcAMP. The coincidence of this peak with $\mathrm{ABP}$ in testis extracts provides additional evidence that the androgen-binding activity component released into the medium by cultured Sertoli cells is ABP.

The similar stimulation of ABP production by Sertoli cell-enriched cultures treated with FSH or cAMP and its derivatives suggests that the action of FSH on Sertoli cells may be mediated by increased cAMP production through activation of the adenylate cyclase system. The activation of adenylate cyclase of Sertoli cells by FSH (Dorrington et al., 1974, 1975; Means, 1974) may therefore be an integral part of the total response of these cells to hormonal stimulation in vivo, since it has been shown that the low testicular ABP levels in hypophysectomized rats are greatly increased after administration of FSH (Vernon et al., 1974; Hansson et al., 1974).

The research was supported by grants from the Canadian Medical Research Council and the Banting Research Foundation. The post-doctoral fellowship support of F.R. was provided by a 
grant from the Netherlands Organization for the Advancement of Pure Research. We thank Ms Kam Lam and Ms Julia Lee for excellent technical assistance, and Mrs Erene Stanley for typing various drafts of this manuscript. We are indebted to Mr Ernest Whitter for preparing and photographing sections for electron microscopy.

\section{References}

Cattanach, B.M., Pollard, C.E. \& Hawkes, S.G. (1971) Sex reversed mice: XX and XO males. Cytogenetics 10, 318-337.

Davis, B.J. (1964) Disc electrophoresis. II. Method and application to human serum proteins. Ann. N.Y. Acad. Sci. 124, 404-448.

DORRINGTON, J.H. \& Fritz, I.B. (1974) Effects of gonadotrophins on cyclic AMP production by isolated seminiferous tubules and interstitial cell preparations. Endocrinology 94, 395-403.

DorRington, J.H., Roller, N.F. \& FriTz, I.B. (1974) Effects of FSH on cell preparations from the rat testis. In Hormone Binding and Target Cell Activation in the Testis, pp. 237-241. Eds M. L. Dufau \& A. R. Means. Plenum Press, New York.

Dorrington, J.H., Roller, N.F. \& Fritz, I.B. (1975) Effects of follicle-stimulating hormone on cultures of Sertoli cell preparations. Molec. Cell Endocr. 3, 59-70.

Dyм, M. (1973) The fine structure of the monkey (Macaca) Sertoli cell and its role in maintaining the blood-testis barrier. Anat. Rec. 175, 639656.

FawcetT, D.F. (1975) Ultrastructure and function of the Sertoli cell. In Handbook of Physiology, Endocrinology Male Reproduction pp. 21-55. Eds R. O. Greep \& D. W. Hamilton. Am. Physiol. Soc., Bethesda, Maryland.

Flickinger, C.J. (1967) The postnatal development of the Sertoli cells of the mouse. Z. Zellforsch. mikrosk. Anat. 78, 92-113.

French, F.S., Mclean, W.S., Smith, A.A., Tindall, D.J., Weddington, S.C., Petrusz, P., Sar, M., STUMPF, W.E., NAYFeh, S.N., HansSON, V., TRYGSTAD, O. \& RitzÉN, E.M. (1974) Androgen transport and receptor mechanisms in testis and epididymis. In Hormone Binding and Target Cell Activation in the Testis, pp. 265-285. Eds M. L. Dufau \& A. R. Means. Plenum Press, New York.

Fritz, I.B., Kopec, B., LAM, K. \& Vernon, R.G. (1974) Effects of FSH on levels of androgen binding protein in the testis. In Hormone Binding and Target Cell Activation in the Testis, pp. 311-327. Eds M. L. Dufau \& A. R. Means. Plenum Press, New York.

Fritz, I.B., Louis, B.G., Tung, P.S., Griswold, M.D., ROMMERTS, F.G. \& Dorrington, J.H. (1975) Biochemical effects of dibutyryl cyclic AMP on cultured Sertoli cells. In Hormonal Regulation of Spermatogenesis. Eds F. S. French, V. Hansson, S. N. Nayfeh \& E. M. Ritzén. Plenum Press, New York.

Hansson, V., Reusch, E., Trygstad, O., Torgersen, O., Ritzén, E.M. \& French, F.S. (1973) FSH stimulation of testicular androgen binding protein. Nature, New Biol. 246, 56-58.
Hansson, V., Trygstad, O., French, F.S., Mclean, W.S., Smith, A.A., Tindall, D.J., Weddington, S.C., Petrusz, P., Nayfeh, S.H. \& Ritzén, E.M. (1974) Androgen transport and receptor mechanisms in testis and epididymis. Nature, Lond. 250, 387-391.

HeIL, A. \& ZILLIG, W. (1970) Reconstitution of bacterial DNA-dependent RNA polymerase from isolated subunits as a tool for the elucidation of the role of the subunits in transcription, FEBS Letters 11, 165-169.

KisSANe, J.M. \& RoBins, E. (1958) The fluorimetric measurement of deoxyribonucleic acid in animal tissues with special reference to the central nervous system. J. biol. Chem. 233, 184-188.

Lowry, O.H., Rosebrough, N.J., FARR, A.L. \& Randall, R.J. (1951) Protein measurement with the Folin phenol reagent. J. biol. Chem. 193, 265275.

Means, A.R. (1974) Early sequence of biochemical events in the action of follicle stimulating hormone on the testis. Life Sci. 15, 371-389.

MurPHY, H.D. (1965) Sertoli cell stimulation following intratesticular injections of FSH in the hypophysectomized rat. Proc. Soc. exp. Biol. Med. 118, 1202-1205.

Ritzén, E.M., French, F.S., Weddington, S.C., NEYFEH, S.N. \& HANSSON, V. (1974) Steroid binding in polyacrylamide gels; quantitation at steady state conditions. J. biol. Chem. 249, 6597-6604.

SANBorn, B.M., Elkington, J.S.H. \& Steingerger, E. (1974) Properties of rat testicular androgen binding protein. In Hormone Binding and Target Cell Activation in the Testis, pp. 291-310. Eds M. L. Dufau \& A. R. Means. Plenum Press, New York.

SAnborn, B.M., Elkington, J.S.H., ChOWdhury, M., TCholakian, R.K. \& Steinberger, E. (1975) Hormonal influences on the level of testicular androgen-binding activity: effect of FSH following hypophysectomy. Endocrinology 96, 304-312.

Steinderger, A. \& Steinberger, E. (1966) In vitro culture of rat testicular cells. Expl Cell Res. 44, 443-452.

Tindall, D.J., Schrader, W.T. \& Means, A.R. (1974) The production of androgen binding protein by Sertoli cells. In Hormone Binding and Target Cell Activation in the Testis, pp. 167-175. Eds M. L. Dufau \& A. R. Means. Plenum Press, New York.

Tung, P., Dorrington, J., Rommerts, F. \& Fritz, I.B. (1974) Structural characteristics of presumptive Sertoli cells grown in culture, and their response to FSH and cAMP. J. Cell Biol. 63, 353a.

Tung, P.S., Dorrington, J.H. \& Fritz, I.B. (1975) Structural changes induced by follicle-stimulating hormone or dibutyryl cyclic AMP on presumptive 
Sertoli cells in culture. Proc. natn. Acad. Sci. U.S.A. 72, 1838-1842.

Vernon, R.G., Dorrington, J.H. \& FriTz, I.B. (1972) Testosterone binding by rat testicular seminiferous tubules. Excerpta Med. Int. Congr. Ser. No. 256, 200.

Vernon, R.G., Kopec, B. \& Fritz, I.B. (1973) Studies on the distribution of the high affinity testosterone binding protein (TBP) in rat testis and seminiferous tubules. J. Endocr. 57, ii.

VeRnON, R.G., KoPEC, B. \& FRITZ, I.B. (1974) Observations on the binding of androgens by rat testis seminiferous tubules and testis extracts. Molec. Cell Endocr. 1, 167-184.

Received 12 February 1975 